https://doi.org/10.31470/2706-7904-2020-15-164-167

\title{
ХАРАКТЕРИСТИКА ЕМОЦИЙНОЇ СКЛАДОВОЇ ФРЕЙМОВОЇ МОДЕЛІ КОНЦЕПТУ ЛОКДАУН
}

\section{Characteristics of the Emotional Component Frame Model of the Lockdown Concept}

\author{
Liubov Letiucha \\ Ph.D. in Philology, Associate Professor \\ Pereiaslav-Khmelnytskyi Hryhorii Skovoroda State Pedagogical University (Ukraine) \\ letinna@ukr.net \\ https://orcid.org/0000-0002-0481-850X

\section{Iryna Bocharova} \\ Ph.D. in Philology, Associate Professor \\ Kyiv National Economic University named after Vadym Hetman (Ukraine) \\ irinabocharova1957@gmail.com \\ https://orcid.org/0000-0003-0370-8410
}

\begin{abstract}
Some attempts to create an emotional characteristic by the linguistic description of the concept LOCKDOWN are accomplished in this article. To reach the aim of this research the frame analysis of a written text was applied as one of the basic methods of analysis concerning mechanisms of interaction in verbal and cognitive structures. Having analyzed a verbal performance, the conclusion was made that the concept LOCKDOWN has got the following emotional characteristic: FEAR as a dominant emotion (fear of uncertainty; fear of illness; fear for life; fear for the nearest and dearest; fear of losing a job (you/parents); fear of losing contacts; fear of staying without a rest); SATISFACTION (satisfaction from not getting early; satisfaction from studying at home; satisfaction from communicating with family/domestic animals). Overall, the emotive characteristic of the concept LOCKDOWN is a combination of dominant destructive (80\%) and constructive (20\%) emotions.
\end{abstract}

Key words: the concept LOCKDOWN, the frame analysis, the emotional characteristic.

\section{Вступ \\ Introduction}

Емоції - складний продукт духовної i пізнавальної діяльності людини. Дослідження емоційних станів людини набуває все більшого поширення в сучасному мовознавстві як прояву антропоцентричної парадигми. 
Складність проблеми вираження емоцій у мові перш за все обумовлює й існування різноманітних підходів до іiі вивчення: лінгвістичного, психолінгвістичного, психологічного, лінгвокультурологічного тощо.

У психолінгвістиці відповідно до філософського принципу співвідношення раціонального та ірраціонального (емоційного) розмежовують раціональний мовленнєвий вплив, для досягнення якого мовець бере на озброєння переконливі факти, аргументи, які впливають на свідомість людей; і емоційний мовленнєвий вплив, мета якого полягає у вираженні мовцем емоцій і досягненні відповідної емоційної реакції у слухача (Івакіна, 1999). Власне, до раціональних засобів мовленнєвого впливу відносяться аргументованість, логічність викладу матеріалу, обгрунтованість і точність викладених фактів тощо. До емоційних засобів відносяться такі засоби, які здатні апелювати до емоцій і почуттів слухачів, схвилювати, вразити, здивувати, засмутити або викликати будь-яку іншу емоційну відповідь.

Традиційна лінгвістика зазвичай вважає, що емоційне і раціональне - явища, протиставні в мові, мовленні, тексті: мова пов'язана 3 мисленням, ці явища взаємодіють синхронно, а емоції дають лише факультативні конотації, наприклад, для розуміння семантики слова. Однак, якщо мова розглядається як найважливіша характеристика людини як мовної особистості, де раціональне і емоційне переплетені та нерозривні, цю тезу можна заперечити (Іонова, 2004).

Мету дослідження вбачаємо у характеристиці емоційної складової при створенні фреймової моделі концепту ЛОКДАУН.

\section{Методи та методики дослідження Methods and Techniques of the Research}

Емоційну характеристику концепту ЛОКДАУН у свідомості сучасної людини доцільно проводити з урахуванням психолінгвістичних методів. У дослідженні ми використали фреймовий аналіз письмового тексту, як один із базових методів аналізу механізмів взаємодії вербальних та когнітивних структур. Перший етап: фіксація усіх слів тексту, що вербально виражені іменниками; Другий етап: групування отриманих іменників у загально визначені категорії, які грунтуються на енциклопедичних знаннях; Третій етап: здійснення підрахунку кількості слів у всіх визначених категоріях та визначення коефіцієнту частотності (Засєкіна \& Засєкін, 2008: 83-84). Матеріалом дослідження слугували закінчення речення, a саме конструкція «Локдаун - це...». Вибірку дослідження, яке проводилося у листопаді 2020 року, склали 30 респондентів, студентів ДВНЗ «Переяслав-Хмельницький державний педагогічний університет імені Григорія Сковороди» віком 17-20 років. 


\section{Результати}

Results

Оскільки сутність концепту «двоїста» - «ментальна і психічна» (Кочерган, 2003) та, в основі концепту лежить «асоціативне нашарування культурних смислів (конотацій) на основне (словникове) значення слова» (Жайворонок, 2004), тому визначення концепту має і емоційний мовленнєвий вплив.

На першому етапі експерименту, використовуючи фреймовий аналіз письмового тексту (психолінгвістична методика закінченого речення) «Локдаун це..», ми отримали асоціативне поле, зафіксоване у свідомості студентів. Його вербалізатори: бути без друзів (1), хвороба (4), смерть(2), втрата роботи(4), втрата спілкування (4), ізолящуія (3), економічна криза (4), неможливість мати літній відпочинок (2), не вставати рано (2), навчатися вдома (3), спілкування з родиною, домашніми тваринами (1). На другому етапі експерименту дані реакції було угруповано у провідні категорії (3): фізичний стан людини, матеріальний стан людини, комунікаџія, які можна вважати базовими структурами концепту ЛОКДАУН. Найбільш представленою категорією $є$ фрейм матеріальний стан людини із наступними вербалізаторами: матеріальний стан людини є: втрата роботи (4), економічна криза (4), неможливість мати літній відпочинок (2). На другому місці $\epsilon$ фрейм комунікація, представлений реакціями: втрата спілкування (4), ізоляція (3), бути без друзів (1). Третю позицію займає фрейм фізичний стан людини, маркований лексемами: хвороба (4), смерть(2).

На рівні емоційної характеристики у свідомості студентів зафіксована та домінує пов'язана із вербальними реакціями деструктивна емоція СТРАХ. Однак реакції - не вставати рано (2), навчатися вдома (3), спілкування з родиною, домашніми тваринами (1) відповідають конструктивній емоції ЗАДОВОЛЕННЯ.

Онлайн slovnyk.ua дає наступне тлумачення аналізованої лексеми, яке є ядром концепту: «ЛОКДАУН, -y, ч. 3. Тимчасовий стан, встановлений державними органами влади (наприклад, під час спалаху епідемічної хвороби), коли люди повинні залишатися в своїх будинках і утримуватися від або обмежувати діяльність поза домом, щзо передбачає контакти з іншими людьми (наприклад, відвідування великих зборів, ресторанів, торгівельних центрів тощу)». Логічність викладу матеріалу, аргументованість, обгрунтованість та точність викладених фактів дефініції дають нам право вважати іiі, перш за все, раціональним засобом мовленнєвого впливу. Водночас, дефініція не позбавлена імпліцитної емоційної характеристики - страху як базової, первинної, елементарної соціалізованої емоції з негативною конотацією, пов’язаної із хвилюванням, 3 неприємними відчуттями та засвідченою дескриптивними засобами 
мовного втілення, що відповідають загально визначеним категоріям: eniдемія, комунікація. Подібне тлумачення слова підтримує такий ряд слів, отриманих у результаті експерименту як хвороба (4), смерть(2), втрата спілкування (4), ізоляція (3), неможливість мати літній відпочинок (2).

Розширення семантики концепту фреймом матеріальний стан людини та його домінантність пояснюється тим, що експеримент проводився восени, коли в різного прояву карантинах країна перебувала вже досить тривалий час, що не могло позначитися на погіршенні матеріального благополуччя людей. Наявність у емоційній характеристиці позитивної емоції ЗАДОВОЛЕННЯ пояснюємо, перш за все, віком реципієнтів.

\section{Висновки \\ Conclusions}

Аналізуючи концепт ЛОКДАУН, ми дійшли висновку про необхідність враховувати емоційну характеристику, оскільки в мові відображається не тільки реальний світ, що оточує людину, але й емоційна реакція на цей світ. Концепт ЛОКДАУН має наступну емоційну характеристику: СТРАХ як домінантна емоція (страх хвороби; страх за своє життя; за життя близьких людей; страх самому/батькам втратити роботу; страх втратити спілкування; страх залишитися без відпочинку); ЗАДОВОЛЕННЯ (задоволення не вставати рано; задоволення навчатися вдома; задоволення більше спілкуватися з родиною/домашніми тваринами). Отже, емоційна характеристика концепту ЛОКДАУН - це поєднання домінувальних деструктивних(80\%) та конструктивних (20\%) емоцій.

\section{Література References}

Жайворонок, В.В. (2004). Етнолінгвістика в колі суміжних наук. Мовознавство, 5-6, 23-32.

Засєкіна, Л.В., \& Засєкін, С.В. (2008). Психолінгвістична діагностика. Луцьк: Вежа.

Ивакина, Н.Н. (1999). Основы судебного красноречия: (Риторика для юристов). Москва: Юристъ.

Ионова, С.В. (2004). Эмоциональная интерференция в тексте. Язык и эмоции: личностные смыслы и доминанты в речевой деятельности, 118-129.

Кочерган, М.П. (2003). Мовознавство на сучасному етапі. Дивослово. Українська мова й література в навчальних закладах, 5, 24-29. 